\title{
De chemist
}

Citation for published version (APA):

Vermande, H. (2021). De chemist: De geschiedenis van een verdwenen beroepsgroep, 1600-1820. [, Maastricht University]. Uitgeverij Verloren. https://doi.org/10.26481/dis.20211021 hv

Document status and date:

Published: 01/01/2021

DOI:

10.26481/dis.20211021hv

Document Version:

Publisher's PDF, also known as Version of record

\section{Please check the document version of this publication:}

- A submitted manuscript is the version of the article upon submission and before peer-review. There can be important differences between the submitted version and the official published version of record.

People interested in the research are advised to contact the author for the final version of the publication, or visit the DOI to the publisher's website.

- The final author version and the galley proof are versions of the publication after peer review.

- The final published version features the final layout of the paper including the volume, issue and page numbers.

Link to publication

\footnotetext{
General rights rights.

- You may freely distribute the URL identifying the publication in the public portal. please follow below link for the End User Agreement:

www.umlib.nl/taverne-license

Take down policy

If you believe that this document breaches copyright please contact us at:

repository@maastrichtuniversity.nl

providing details and we will investigate your claim.
}

Copyright and moral rights for the publications made accessible in the public portal are retained by the authors and/or other copyright owners and it is a condition of accessing publications that users recognise and abide by the legal requirements associated with these

- Users may download and print one copy of any publication from the public portal for the purpose of private study or research.

- You may not further distribute the material or use it for any profit-making activity or commercial gain

If the publication is distributed under the terms of Article $25 \mathrm{fa}$ of the Dutch Copyright Act, indicated by the "Taverne" license above, 
'Chemist' is een verouderd Nederlands woord voor 'chemicus' of 'scheikundige': iemand die verstand heeft van de scheikunde of de scheikunde beoefent. Tot in de $19^{\circ}$ eeuw was het ook de naam van een beroep: het was iemand die chemicaliën, met name chemische geneesmiddelen, produceerde en verkocht. De chemist positioneerde zich zeker anderhalve eeuw (1670-1820) op de farmaceutische markt als zelfstandige leverancier van 'chimicalia' en medicijnen, naast de apotheker en de drogist.

Dit boek beschrijft de fascinerende geschiedenis van de opkomst, bloei en neergang van de beroepsgroep van de chemisten in Nederland en de eeuwenlange strijd tussen apothekers en chemisten over de (chemische) geneesmiddelenbereiding. Tot enige vorm van institutionalisering van het chemistenberoep in de vorm van gereguleerde opleidingen, een corporatieve organisatievorm en een diplomastructuur is het in Nederland nooit gekomen. Dit zal een van de redenen zijn dat er over de chemisten heel weinig bekend is, en het beroep van de chemist in de geschiedschrijving van zowel de farmacie, de chemie als de geneeskunde tussen wal en schip is gevallen. In deze studie vult Henk Vermande dit hiaat.

Dechemisten hadden een gemeenschappelijk uithangteken: de salamander-in-hetvuur, embleem van de chemische bereiding van geneesmiddelen. Met dit uithangteken konden de chemisten zich onderscheiden van de apothekers met hun vijzel, de drogisten met hun gaper, en de distillateurs-brandewijnbranders met hun distilleerketel. De herkomst van het salamander-uithangteken vanuit de alchemie wordt in dit boek beschreven.
Henk

Vermande

\section{DE CHEMIST}

DE GESCHIEDENIS VAN EEN VERDWENEN BEROEPSGROEP,

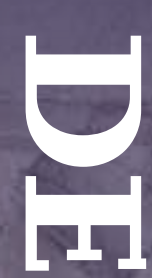

2

나모

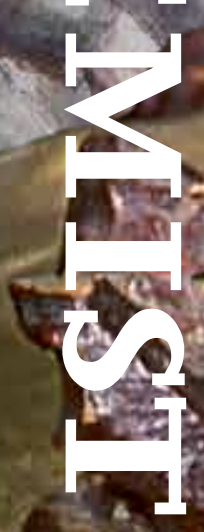

e

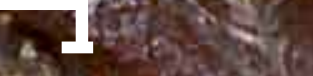

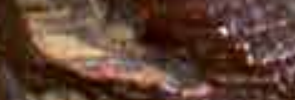
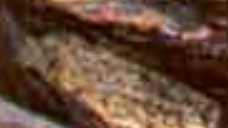

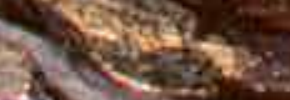

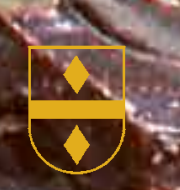

\section{Henk Vermande}

